Colonies; Mr. F. S. Collier, forestry adviser to the Secretary of State for the Colonies; Prof. M. McG. Cooper, professor of agriculture and rural economy, King's College, University of Durham; Dr. W. Davies, director of the Grassland Research Institute ; Prof. A. N. Duckham, professor of agriculture, University of Reading; Sir Frank Engledow, professor of agriculture, University of Cambridge ; Mr. G. Lacey, adviser on drainage and irrigation to the Secretary of State for the Colonies; Mr. D. Martin, of Unilever, Ltd. ; Mr. R. S. Marshall, adviser on animal health to the Secretary of State for the Colonies; Mr. D. Rhind, Secretary for Colonial Agricultural Research ; Sir William Slater, secretary of the Agricultural Research Council. The technical secretary of the Council is Mr. L. Lord, assistant agricultural adviser to the Secretary of State for the Colonies, and the secretary is Mr. A. S. Gann, of the Colonial Office.

\section{Shortage of Scientific Workers in Great Britain}

A PAPER entitled "Technical Education-Shortage of Scientists, Technologists and Technicians", prepared for private circulation by Mr. John Wellens (24 Mossley Road, Grasscroft, near Oldham, Lancs), comments on the Government's recent White Paper, suggesting that the White Paper offers little that is new and effective and supporting Lord Simon of Wythenshawe's recent proposal for a Royal Commission of inquiry. Mr. Wellens suggests that a Commission should be established and directed to report within six months. It should examine such major problems as the distinction between tech. nologist and technician, the training appropriate to each, and the practicability or otherwise of training both in the same institutions. Mr. Wellens stresses that a number of questions demanding urgent examination are glossed over or ignored in the White Paper, and thus the Commission should also consider the quantitative demand and its relation to the demands of other sections of our national life, the extent of the existing wastage and its prevention, the avenues and opportunities of co-operation between education and industry in technical education, apprenticeship and its problems, the utilization of technologists, and the purpose and place of the technical schools. The Commission as a result would prepare a national policy or plan and recommend the type of agency required to see that the plan is put into operation.

Mr. Wellens does not refer to the 'sandwich' scheme of courses; but he himself recommends that the proposed central agency should be so equipped, staffed and financed as to have additional functions, such as research, the continuous collecting and dissemination of information and consulting services. It should be responsible for keeping permanently in touch with appropriate agencies in other countries and should function continuously and actively. Those universities with a major interest in tech. nology should establish chairs of industrial education to promote independent research. Mr. Wellens's concern appears to be to obtain as a matter of urgency constructive answers to the vital questions which he indicates and which the Government has largely ignored.

\section{History of Science in India}

AT a meeting of the Council of the National Institute of Sciences of India, held in May 1955, the question of compiling a history of science in India was considered (Sci. and Cul., 21, No. 8; February 1956). It was decided that this history, when written, should be divided into three periods, namely, the earliest years up to A.D. 1200, the medieval period A.D. 1201-1800 and the British period A.D. 18011950. It was also decided to invite the views of existing institutes and academies in the country which are in a position to undertake this type of work. These include the Bhandarkar Institute, Poona, and the Asiatic Society, Calcutta. The idea of writing such a history of science was first mooted in November 1951 at a symposium on the history of sciences in South Asia, held in Delhi under the joint auspices of the National Institute of Sciences of India and Unesco. At the symposium the National Institute was invited to convene a group to study the history of science in India. In view of the expenses which will be involved, the National Institute has decided to approach the Government of India for a grant under the Second Five Year Plan to undertake the project it has in mind.

\section{Virus Transmission by Aphids}

M. F. DAy has reported on experiments undertaken with the view of determining the mechenism of the transmission of the potato leaf-roll virus by aphids (Austral. J. Biol. Sci., 8, 4, 498; 1955). He states that the virus causing potato leaf-roll can be recovered from the hæmolymph of Myzus persicae, the aphid vector. Infective virus has also been separated from the bodies of infected vectors. The virus can be transmitted by an aphid after a moult, and infectivity is retained for at least eight days; during this time the aphid is ablo to infect many plants. $M$. persicae is a much more efficient vector than Macrosiphum euphorbiae. Experiments suggest that the virus multiplies to a limited extent in $M$. persicae. When this vector feeds on a plant containing a low concentration of virus there is generally a latent period. (of approximately $20 \mathrm{hr}$. at $25^{\circ} \mathrm{C}$.) between the acquisition feed and a successful inoculation feed. When the vector foeds on a source of high virus concentration, occasional transmission is obtained with short (approximately $2 \mathrm{hr}$.) acquisition and inoculation feeds. However, the percentage of transmissions under these conditions with the local strain of $M$. persicae is lower than that reported by American workers. No clonal differences in vector efficiency were found. Attempts to isolate strains of leaf-roll virus with different vector relation. ships wero unsuccessful. The relevance of these results to the mechanism of transmission of viruses by insects is discussed. It is suggested that the occurrence of a latent period in a virus vector is indicative of the passage of the virus from the midgut into the salivary glands via the hæmocœle, and the multiplication of the virus in that vector.

\section{National Research Council, Canada : Awards for 1956-57}

The National Research Council, Canada, has made 269 awards for $1956-57$, totalling 345,500 dollars in value. They include 65 bursaries ( 800 dollars each) and 155 studentships $(1,200$ dollars each), tenable in Canada. Of the awards for study abroad, twenty. seven special scholarships, worth 2,000 dollars each, have been granted which will be held in the following countries: fifteen in Great Britain, nine in the United States, two in Sweden and one in France. Twenty-two postdoctorate overseas fellowships, worth 2,500 dollars each, have been granted for work in 